\title{
Altı Yaş Grubu Çocukların Dil Kullanımına Yaratıcı Dramanın Etkisi
}

\author{
Yaşare AKTAŞ ARNAS. Binnur CÖMERTPAY.* Hatice SOFU... \\ Çukurova Üniversitesi
}

\begin{abstract}
Özet
Bu çalışmada Çukurova Üniversitesi Anaokuluna devam eden 6 yaş grubu çocuklarda dil gelişiminde yaratıcı dramanın etkisi incelenmiştir. Ankara Gelişim Tarama Envanteri uygulanarak 7 'si kontrol grubu, 7'si deney grubunu oluşturmak üzere 14 çocuk seçilmiştir. Kontrol grubundaki çocuklar kendi eğitimcileri ile mevcut programı izlemiştir. Buna karşın, deney grubundaki çocuklara öntestten sonra mevcut programa ek olarak yaratıcı drama eğitimi verilmiştir. Çocukların dil kullanımını zenginleştirmek amacıyla hazırlanan 15 yaratıcı drama etkinliği 8 hafta boyunca haftada iki kez olmak üzere uygulanmıştır. Hikaye ve oyun etkinlikleri sırasında kaydedilen veri, çeviri yazıya dönüş̧ürülmüştür. Her çocuğun ilk 35 tümcesi sözcük saylsl, tümce uzunluğu ve farklı sözcük türleri açısından incelenmiştir. Sonuçlar, yaratıcı drama etkinliğine katılan çocukların kontrol grubundaki çocuklara göre daha çok sözcük, daha uzun ve karmaşık tümce kullandıklarını göstermiștir. Bu nedenle, okul öncesi ögretmenlerine sınıflarında yaratıcı drama etkinliklerini kullanmaları önerilmektedir.
\end{abstract}

Anahtar sözcükler: Yaratıcı drama, dil edinimi, okul öncesi eğitim, dil gelişimi

\begin{abstract}
This study aims to find out the effect of creative drama on the development of language use of sixyear-old children attending Çukurova University Kindergarten. Fourteen children, seven in the control group and seven in the experimental group were chosen at the end of assessment with Ankara Developmental Assessment Inventory. The children in the control group were taught by their own instructor following the curriculum; whereas, the children in the experimental group were introduced creative drama after the pretest. Fifteen creative drama activities enhancing their language use were applied twice a week for a duration of 8 weeks. The data collected through games and story telling activities were recorded and transcribed. The first 35 utterances children used were analyzed in terms of sentence length, word counts, and different word classes. The results showed the children who received creativer drama sessions used more words and longer and more complex sentence structures than those who did not. It is suggested that preschool teachers should use creative drama in their classroom activities.
\end{abstract}

Keywords: Creative drama, language acquisition, pre-school education, language development

\footnotetext{
Prof. Dr., Çukurova Üniversitesi, Eğitim Fakültesi, E-posta: yasare@cu.edu.tr

•Blm.Uzm., Çukurova Üniversitesi, Eğitim Fakültesi, E-posta: comertpay@gmail.com

...Doç.Dr., Çukurova Üniversitesi,Eğitim Fakültesi,E-posta: hasofu@cu.edu.tr
} 


\section{Giriş}

Dil edinimi çocuklar doğar doğmaz başlayıp yaşam boyu devam eden bir süreçtir. Ancak, bu süreç yaşamın ilk yıllarında daha yoğun ve hızlı, daha sonraki yıllarda ise daha yavaş gelişir. Çocuklar, herhangi bir dilin konuşulduğu ortama doğarlar ve çevrelerinde konuşulan dilin harekete geçirdiği doğuştan getirdikleri dil edinim yeteneği sayesinde dili edinirler. Bir dilin edinimi yaşamın ilk 6 yılında büyük ölçüde tamamlanır. Çocuğun yaşam koşulları, aile içi iletişim ve edinilen dilin özellikleri gibi etmenler, bu sürecin doğasını belirler. Örneğin Türkçe, çekim eklerinin düzenli olması, her ekin çoğunlukla bir tek işlevinin olması, ekin sözcük içinde kolayca ayırt edilebilir olması nedeniyle erken edinilen bir dildir. Türkçe'yi edinen çocuklar, yaşamlarının ilk iki yılında dilin yapılarının çoğunu edinir, daha sonraki yıllarda az sayıda dilbilgisel yapılar ve daha çok sözcük öğrenmeye devam ederler (Koç ve Slobin, 1985).

Dil kullanımı konuşmacının bireysel özelliklerine göre değişmekle birlikte, bir dili konuşan tüm bireylerin ortak bir dil bilgisi vardır. Çeşitlilikler daha çok bölgesel, toplumsal konuşma özellikleri, sesletim ve sözcük dağarcığı alanındadır. Örneğin, Sofu'ya (1995) göre, Türkçe 'yi edinen çocuklar iki yaş civarında 30-109 arası sözcük kullanırken bu sayı aynı çocuklar üçbuçuk yaşına vardıklarında 630979 arasına ulaşır. Edinilen aylık ortalama sözcük sayısı ise 33 ile 48 arasında değişmektedir. Bu çalışmada farklı sosyo-ekonomik seviyelerden gelen çocukların sözcük dağarcıklarının sayısal farklılıktan çok içerik açısından farklılık gösterdiği ileri sürülmektedir. Kullanılan sözcükler yaşanılan çevreye, aile içi etkileşimin doğasına ve ailenin çocuğa yönelttiği dil ve iletişimin özelliğine göre değişmektedir.

Çocukların erken dönemde edindiği sözcüklerin sözcük türleri açısından dağılımı da dillere göre farkl11ı göstermektedir. Genel olarak ilk iki y1lda ad türü sözcükler daha fazla kullanılmakta ise de daha sonra çocuğun edindiği dilin yapısına göre odaklanılan sözcükler farklılaşmaktadır. Örneğin, İngilizce’yi edinen çocuklar daha çok ad ve ad soylu sözcükler kullanırken, Türkçe 'yi edinen çocuklar iki yaşından sonra göreceli olarak daha fazla eylem kullanmaktadırlar. Çocukların sözcük türlerine ilişkin bu tercihi anne-babaların onlara yönlendirdiği dille de uyum sağlamaktadır. Ancak, dil zenginliği farklı sözcük türlerinin kullanımını ve özellikle de ön ad ve belirteçlerin kullanılmasını gerektirir (Gentner, 1982; Küntay ve Slobin, 1996; Türkay-Altınkamış, 2005).

Yakın çevre edinilen dili yapılandırmada çok önemlidir. Çocuklarda dil edinim becerileri ilk olarak onlara bakanlardan duydukları şarkılar, oyunlar, hikayeler ve sesleri dinleyerek gelişir. İlerleyen süreçte çocukların çevresinde gördüğü diğer insanları taklit etmesi, diğer çocukların oyunlarına katılması ve başkaları ile iletişim kurması ile bu beceriler gelişmeye devam eder. Bu edinim çocukların dili 
kullanması, sözcüklerin, seslerin ve dil yapılarının farkındalığını kazanması ile güçlenir (Alber ve Foil, 2003).

Dil gelişiminin ilk aşamalarında çocukların birbirleri ile ya da bir yetişkinle konuşarak iletişim kurması ve okul öncesi eğitimde sınıf ortamında çocuğun farklı uzunluktaki konuşmalara istekli katılarak deneyim kazanması önemlidir. Fakat çocukların bu tip konuşmalara içinde bulundukları dil ve düşünce yapısından dolayı istekli katılmaları zor olabilmektedir. Öğretmenler küçük yaştaki çocukların dil becerilerini oyun ve yaratıcı drama gibi etkinliklerle destekleme firsatına sahiptirler.

Dil edinimini en iyi şekilde geliştirme ve eğitme ortamı "doğal" ortamdır. Okul öncesi dönemi çocuğu için en uygun doğal ortam, kendisinin doğrudan katıldığı, oluşturduğu "oyun" ortamı gelişim ve eğitim açısından büyük değer taşır. Dil kullanımını gerektiren gerçek ortamların yanısıra eğitimde gerçeğe benzer bağlamlar yaratarak dil kullanımını çeşitlendirmenin bir yolu da okul öncesi eğitimde yaratıcı drama uygulamasıdır. Yaratıcı drama , "doğal” (gerçeğe yakın) ortamlarıyla, iletişim becerileri ve dil gelişimi için çocuğa katkı sağlar. Canlandırmalar sırasında çocuklar anlaşılmak için birbirlerini dinlemeye ve daha dikkatli konuşmaya ihtiyaç duyarlar. Bu durum çocukların doğal bir şekilde ses tonlarına, diksiyonlarına, konuşma hızlarına dikkat ederek uygun konuşma alışkanlıkları kazanmasını sağlayabilir. Yaratıcı dramanın bu özelliği dikkate alındığında konuşma eğitimi için çocuklara konuşma egzersizi yapma şansı verir. Aynı zamanda süreç içerisinde çocukların bir dev, prens, kraliçe, yaşlı bir adam, öğretmen, anne, bebek, doktor, bir hayvan gibi çeşitli rollere girmesi onları farklı konuşma türleri ile tanıştırabilir.

Yaratıcı drama, sadece çocukların ifade şekillerini değil sözcük dağarcıklarının gelişimini de destekleyen bir etkinliktir. Yaratıcı drama süreci içerisinde çocuklar daha önce bilmedikleri yeni bir konu ile karşılaşabilir. Bu ilk deneyim, çocukların süreç içerisinde ilk defa karşılaştıkları bu sözcükleri sık sık kullanarak yeni sözcükler öğrenmelerini sağlayabilir. Soyut sözcüklerin öğreniminde de yaratıcı drama bir yöntem olarak kullanılabilir. Eğitimciler bu yöntemi kullanarak çocukların soyut sözcükleri ve kavramları hareketler yolu ile canlandırıp ifade ederek daha kolay öğrenmelerini sağlayabilir (McCaslin, 1990).

Karşısındakini doğru anlama ve kendini ifade ederken uygun sözcük kullanma çocuğun erken yaştan itibaren edindiği önemli becerilerdir. Bunları yaratıcı drama ile gerçekleştirmek çocuklara öğrenilen becerileri sınama ve dili kullanmada yaratıcı olma şansı tanır (Alber ve Foil, 2003).

Yaratıcı drama, sözel dilin yanında sözel olmayan ögelere de yer vererek, konuşmaya derinlik ve anlam kazandırır. Yaratıcı drama uygulamalarında, “-mış gibi” durumu yaratma ve ifade etme yaratıcı dramanın bir parçası olarak konuşmanın doğal olarak oluşmasını sağlayacaktır. Yaratıcı drama sürecinde 
çocuklar kendilerini bireysel ya da grubun bir üyesi olarak ifade edebilirler. Çocuklardan istenilen sadece bilişsel olarak değil, duygusal olarak da kendilerini ifade etmeleridir. Bu şekilde dil ve deneyim birleşimi gerçekleşir. Yaratıcı drama içerisinde çocukların belirlenen hedef doğrultusunda tüm konuşma türlerini denemeleri mümkündür. Yaratıcı drama ile çocuklar herhangi bir yerde, herhangi bir kişiyle, herhangi bir zamanda konuşma şansına sahiptirler. Yaratıcı drama da nereden başlanacağını seçerek sonra ne olacağını belirlemek çocuğun söyleyeceği şeye bağlıdır. Buna bağlı olarak çocuk gelişen olay ve problemler hakkında bilgi vererek etkin olarak konuşmaya katılacaktır. Yaratıcı drama, ayrıca çocukların düşünmelerini sağlamak ve yaşadıkları dünya ile ilgili soru sorma yeteneklerini geliştirmek açışından da önemli bir fırsattır (Toye ve Prendiville, 2000).

Toye ve Prendiville (2000)'e göre yaratıcı drama konuşma için bir bağlam yaratarak, yeni hayali roller ve bakış açıları oluşturarak, yeni ilişkiler geliştirerek dil kullanımına katkıda bulunur. Yaratıcı drama sayesinde öğretmenin tek yönlü monoloğundan çocuklarla diyaloğa geçilir, dinleme gelişir, yaratıcı dramadaki çember şeklindeki oturma düzeni çocukların birbirini görmesini sağlayarak iletişimi güçlendirir.

Tüm bu görüşlerden yola çıkarak, bu çalışmada yaratıcı drama etkinliklerinin 6 yaş çocuklarında dil kullanımına etkisinin incelenmesi amaçlanmıştır.

\section{Yöntem}

$\mathrm{Bu}$ araştırma, yaratıcı drama etkinliklerinin 6 yaş grubu çocukların dil kullanımına etkisini araştırmak amacıyla gerçekleştirilen "ön test-son test kontrol gruplu” deneme modeline göre geliştirilmiş yarıdeneysel bir çalışmadır. Bu çalışmada, özellikle çocukların kullandıkları sözcük türü, sözcük sayısı, tümce uzunlukları ve tümce yapıları incelenmiştir.

Eğitim ile ilgili araştırmalarda çoğu zaman araştırmacılar için deneysel bir çalışma yürütmek çok kolay değildir. Çünkü deneysel çalışmalar kontrollü koşullarda sistemli değiş̧iklikler yapılması ve sonuçlarının izlenmesi ile yapılan çalışmalardır. Deneysel çalışmalarda bağımsız değişkendeki sistemli değişmelerin bağımlı değişkeni nasıl etkilediği görülmeye çalışılır. Buna karşın eğitim ile ilgili yapılan çalışmalarda tüm değişkenlerin kontrol altına alınması ve eşitlenmesi çok zordur. Bu nedenle bu çalışma yarı-deneysel bir çalışmadır.

\section{Çalışma grubu}

$\mathrm{Bu}$ araştırmanın çalışma grubunu Çukurova Üniversitesi Anaokuluna devam eden altı yaş grubu çocuklar oluşturmaktadır. Yaratıcı dramanın çocukların dil kullanımına etkisini belirlemek amacı ile aynı okuldan tesadüfi örneklem yoluyla iki sınıf seçilmiştir. Çalışmanın başında bu iki sınıftaki 
çocuklara "Ankara Gelişim Tarama Envanterinin” dil gelişimi bölümü uygulanarak çocukların dil gelişimleri eşitlenmeye çalışılmıştır.

Çalışmanın başlangıç aşamasında deney ve kontrol grupları için 14'er çocuk seçilmiştir. Her iki grup için 14'er çocuk seçilmesinin amacı küçük yaş gruplarında yapılan yaratıcı drama çalışmalarında çocuk sayısının 14 olarak sinırlandırılmasının önerilmesidir (Adıgüzel, 2002). Ancak son test verilerinin toplanması aşamasında çalışmanın yaz dönemine gelmesi nedeniyle deney ve kontrol gruplarındaki bazı çocuklar anaokuluna devam etmemişler ve bu çocuklardan veri toplanamamıştır. Bu nedenle bu çalışma ön ve son test verileri alınabilen 7'şer çocuk üzerinden değerlendirilmiştir.

\section{Veri Toplama Araçlart}

Ankara Gelişim Tarama Envanteri: Savaşır, Sezgin ve Erol (2005) tarafından geliştirilen ve geçerlik güvenirlik çalışması yapılan Ankara Gelişim Tarama Envanteri hem genel gelişim hem de dört farklı gelişim alanında (Dil-Bilişsel, İnce Motor, Kaba Motor, Sosyal Beceri-Özbakım) yaş düzeyi altında gelişim gösteren çocukların belirlenmesi amacıyla kullanılan ve 154 sorudan oluşan bir değerlendirme aracıdır.

Envanter uygulanırken çocuğun takvim yaşından başlayarak sorular sorulmakta ve birbirini izleyen sekiz soruya yanlış cevap verildiğinde de görüşme sonlandırılmaktadır. Puanlamada çocuğun başlama noktasından önceki bütün soruları cevapladığı esas alınmakta ve kesme noktasına kadar her doğru cevaba "bir" her yanlış cevaba "sıfır" puan verilmektedir.

Ses Kayıt Cihazı: Çocukların kullandıkları ifadelerin, dil edinimi yönünden incelenmesi amacıyla çocuklarla yapılan ikişerli görüşmeler sırasında kullanılan ses kayıt cihazı, sesi düşük, normal ve yüksek seviye şeklinde sesi kaydedebilen, kaydettiği sesleri bilgisayara aktarabilen dijital özelliklere sahiptir. Pil ile çalışabilen bu cihaz 16 yüksek seviyede kayıt alabilmektedir. Bilgisayara aktarılan bu kayıtlar cihaza ait özel bir programla çalışmakta ya da mp3 formatına çevrilerek dinlenebilmektedir.

Resimli Hikaye Kitabı: Çocukların uygulama öncesinde ve sonrasında kullandıkları ifadelerin dil edinimi yönünden incelenmesi ve ses kayıtlarının alınması için Türkçe etkinlikleri sırasında hikaye kitapları kullanılmıştır. Kullanılan kitaplar uzman görüşüne sunularak seçilmiştir. Hikaye kitaplarının seçiminde, kitaplarda kullanılan dilin, ifadelerin, resimlerin, renklerin ve hikayenin içeriğinin çocukların yaş gelişimine uygun olup olmaması temel alınmıştır. Buna göre 5-6 yaş çocukların gelişimine uygun resimli ve 16 sayfalık "Mikrobun Ettikleri” ve "Ah Bir Büyüsem” adlı iki kitap seçilmiştir.

\section{Verilerin Toplanması}

Her iki grupta da veriler serbest oyun ve Türkçe etkinliği sırasında toplanmıştır. Türkçe etkinliğinde, uygulayıcılardan biri çocuklara daha önceden seçtiği hikayelerden birini okumuş ve daha sonra 
çocuklardan sırası ile okuduğu hikayeyi anlatmalarını istemiştir. Ayrıca bu etkinlikte uygulayıcı çocuklara hikayeye ilişkin çeşitli sorular sormuştur. Bu sırada çocukların konuşmalarını ses kayıt cihazına kaydetmiştir. Daha sonra bu kayıtlar da çeviri yazıya dönüştürülmüştür.

Oyun etkinliğinde verileri toplayabilmek için birbiri ile oynamaktan hoşlanan çocuklar ikişerli olarak gruplandırılmıştır. Daha sonra ikili olarak gruplandırılan bu çocuklar daha önceden belirlenen oyun ortamında serbest oyun etkinliğine yönlendirilmişlerdir. Çocukların kendi sınıflarının ya da yabancılık çekmemeleri için önceden bildikleri başka boş bir sınıfın seçtikleri bir köşesi oyun ortamı olarak belirlenmiştir. On beş dakika süren etkinlik süresince çocukların konuşmaları önce ses kayıt cihazına kaydedilmiş, daha sonra bu kayıtlar çeviri yazıya dönüştürülmüştür.

\section{Uygulama}

\section{Deney grubuna yapılan uygulama}

Yaratıcı drama etkinliklerinin uygulamalarına ön test verilerinin toplanmasından sonra başlanmıştır. Deney grubu ile çalışmaya, çocukların yaratıcı drama ile tanışması ve eğitimcinin çocuklarla çalışırken çocukların deneyim kazanması için bir ön program ile başlanmıştır. Programda çocuklara "donuk imge, sözsüz oyun, rol oynama, yaratıcı dramatizasyon” gibi yaratıcı drama tekniklerini içeren beş ön çalışma yapılmıştır.

Yapılan ön çalışma sonunda, daha çok çocukların dil edinimlerini destekleyen, çocukların duygu ve düşüncelerini sözel olarak ifade etmesini sağlayan ve 15 etkinlikten oluşan yaratıcı drama etkinliklerine yer verilmiştir. Yaratıcı drama etkinlikleri haftada iki çalışma olmak üzere yaklaşık 8 hafta sürmüştür. Yapılan her bir yaratıcı drama çalışması çocukların dil kazanımlarına yönelik etkinliklerden oluşmaktadır. Yaratıcı drama etkinlikleri araştırmacılardan biri tarafından uygulanmıştır. Uygulanan her yaratıcı drama etkinliği ortalama 45 dakika sürmüştür.

Uygulanan yaratıcı drama etkinlikleri, çocukların dili etkin olarak kullanmalarını sağlayacak, hikaye ve konulara dayalı doğaçlamaların yer aldığı etkinliklerdir (örnek için Bkz Ek1). Bu etkinlikler, Mages (2008) tarafından yapılan literatür değerlendirmesinde yaratıcı drama etkinliklerinin dil gelişimine katkısına ilişkin çalışmalarda kullanılan etkinliklerle paralellik göstermektedir.

\section{Kontrol grubuna yapılan uygulama}

Kontrol grubunda uygulamacılardan biri, Türkçe etkinlikleri saatlerinde haftada iki defa olmak üzere toplam 8 hafta etkinliklere katılarak etkinliği sürdürmüştür. Kontrol grubunda uygulamacı öğretmenin günlük planında belirlediği amaç ve kazanımlara göre çeşitli Türkçe etkinlikleri gerçekleştirmiştir. Uygulamacı çocuklara bazen öğretmen tarafından amaç ve kazanımlarına göre seçilen hikaye kitaplarını okurken bazen de herhangi bir hikayeyi hikaye kartı, televizyon şeridi gibi farklı hikaye anlatma 
tekniklerini kullanarak anlatmıştır. Etkinlik sonrasında uygulamacı çocuklardan dinledikleri hikayeyi anlatmalarını istemiş ve çocuklarla hikaye hakkında sohbet edilerek etkinlik sonlandırılmıştır.

\section{Verilerin Analizi}

Oyun etkinliği ve Türkçe etkinlikleri sırasında elde edilen veriler bilgisayar ortamına aktarılarak yazılı metinler haline getirilmiştir. Elde edilen bu metinlerden her çocuk için hikaye metinlerinden kullandıkları ilk 35, oyun metinlerinden kullandıkları ilk 35 olmak üzere toplam 70 tümce seçilerek bu tümcelerin, sözcük sayısı, tümce uzunlukları ve tümce içerisinde kullanılan ad, eylem, belirteç, sıfat, bağlaç, ortaç ve ulaçlar incelenmiştir.

\section{Bulgular ve Yorum}

Yaratıcı dramanın okul öncesi çocukların dil kullanımları üzerine etkisinin incelenmesi amacı ile planlanan bu çalışmanın verileri değerlendirilerek aşağıda Tablolar halinde sunulmuştur.

Tablo1. Çocukların Kullandıkları Toplam Sözcük Sayısı ve Mann-Whitney U Testi Sonuçları

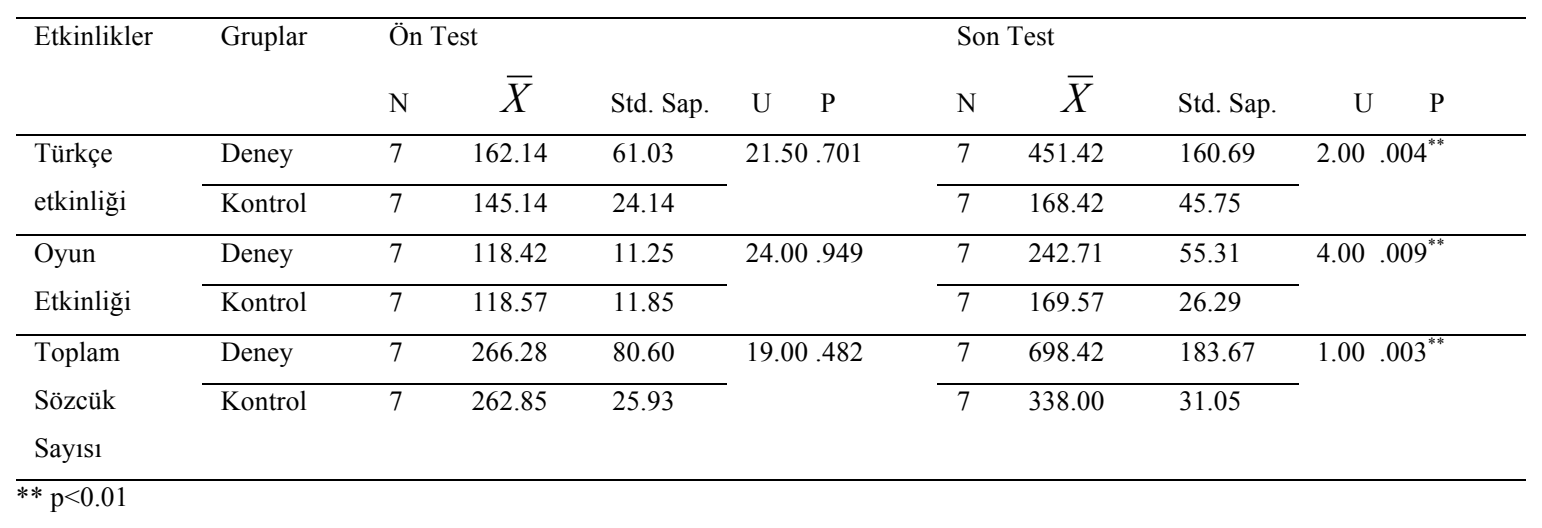

Kullanılan toplam sözcük sayısına bakıldığında, ön testte hem deney hem de kontrol grubundaki çocukların oyun ve dil etkinliklerinde ortalama olarak birbirine yakın sayıda sözcük kullandıkları gözlenmiştir. İki etkinliğin ortalama toplam sözcük sayısı deney grubu için 266.28 , kontrol grubu için ise $262.85^{\prime}$ tir. Son testlerde deney grubu ortalama 698.42 sözcük kullanırken, kontrol grubu 338 sözcük kullanmıştır. Her iki etkinlik ayrı ayrı incelendiğinde ise son testlerde deney grubundaki çocukların hem oyun etkinliğinde ( $\bar{X}=242.71$ ) hem de Türkçe etkinliğinde ( $\bar{X}=451.42)$ kullandıkları ortalama sözcük sayısının kontrol grubundaki çocukların ortalama sözcük sayısından (oyun 169.57, Türkçe 168.42) daha fazla olduğu belirlenmiştir. 
Yapılan istatistiksel analizler sonucunda da son testlerde hem oyun etkinliğinde ( $U=4.00 \mathrm{p}<.001)$ hem de Türkçe etkinliğinde $(\mathrm{U}=2.00 \mathrm{p}<.001)$ deney ve kontrol grubundaki çocukların kullandıkları ortalama sözcük sayıları arasındaki farkın istatistiksel olarak anlamlı olduğu saptanmıştır.

Tablo 2. Çocukların Bir Tümcede Kullandıkları Ortalama Sözcük Sayısı

\begin{tabular}{|c|c|c|c|c|c|}
\hline \multirow[t]{2}{*}{ Etkinlik Türü } & \multirow[t]{2}{*}{ Çocuk Sayıs1 } & \multicolumn{2}{|c|}{ Deney Grubu } & \multicolumn{2}{|c|}{ Kontrol Grubu } \\
\hline & & Ön Test & Son Test & Ön Test & Son Test \\
\hline \multirow[t]{8}{*}{ Oyun Etkinliği } & 1. çocuk & 3.34 & 6.02 & 3.45 & 3.05 \\
\hline & 2.çocuk & 3.82 & 6.02 & 2.71 & 3.22 \\
\hline & 3 çocuk & 3.00 & 5.74 & 3.25 & 3.17 \\
\hline & 4 çocuk & 3.28 & 4.94 & 3.31 & 5.62 \\
\hline & 5 çocuk & 2.90 & 4.65 & 3.31 & 3.54 \\
\hline & 6 çocuk & 3.48 & 4.65 & 3.14 & 3.14 \\
\hline & 7 çocuk & 3.00 & 4.66 & 3.71 & 3.77 \\
\hline & Ortalama & 3.26 & 5.25 & 3.26 & 3.63 \\
\hline \multirow[t]{8}{*}{ Türkçe etkinliği } & 1. çocuk & 4.11 & 6.88 & 3.42 & 2.37 \\
\hline & 2.çocuk & 4.25 & 8.25 & 4.74 & 4.08 \\
\hline & 3 çocuk & 3.57 & 9.54 & 3.85 & 4.17 \\
\hline & 4 çocuk & 3.94 & 6.22 & 3.28 & 5.31 \\
\hline & 5 çocuk & 3.65 & 6.91 & 3.48 & 4.74 \\
\hline & 6 çocuk & 3.97 & 7.37 & 4.11 & 6.08 \\
\hline & 7 çocuk & 4.11 & 8.05 & 4.82 & 3.57 \\
\hline & Ortalama & 3.94 & 7.60 & 3.95 & 4.33 \\
\hline
\end{tabular}

Tablo 2 incelendiğinde ön testler sonucunda hem deney hem de kontrol grubundaki çocukların oyun (hem deney hem de kontrol grubu 3.26 sözcük) ve Türkçe etkinliklerinde (deney grubu 3.94, de kontrol grubu 3.95 sözcük) bir tümcede ortalama olarak eşit sayıda sözcük kullandıkları bulunmuştur. Son testler sonucunda ise hem oyun etkinliğinde hem de Türkçe etkinliğinde deney grubundaki çocukların (oyun 5.25, hikaye 7.60) kullandıkları ortalama sözcük sayısının kontrol grubundaki çocukların ortalama sözcük sayısından (oyun 3.63, hikaye 4.33) daha fazla olduğu belirlenmiştir.

Yapılan istatistiksel analizler sonucunda da deney ve kontrol grubundaki çocukların ortalama sözcük sayıları arasındaki farkın istatistiksel olarak anlamlı olduğu ve deney grubundaki çocukların sözcük sayılarının kontrol grubundaki çocuklardan daha fazla olduğu saptanmıştır $(\mathrm{p}<0.01)$. Aradaki farklılığın bu kadar fazla olması sadece sözcük dağarcı̆̆ındaki dönemsel artıştan kaynaklanmayabilir. Bunun yanısıra, yaratıcı dramanın doğası gereği edilgen durumda olan sözcük dağarcığını harekete geçirdiği düşünülebilir. $\mathrm{Bu}$ şekliyle, yaratıcı dramanın dilin hem edinimine hem de olan dağarcığın etkin kullanımına yardımcı olduğu söylenebilir (Alber ve Foil, 2003).

Ayrıca, bu çalışmanın sonuçları daha önce yapılmış olan çalışmaların sonuçlarını destekler niteliktedir. Örneğin, Uyar (1995) anaokuluna devam eden çocuklara uygulanan yaratıcı drama programının 
çocukların dil edinimine etkisinin incelendiği çalışmada, erken çocuklukta yaratıcı dramanın çocukların kullandıkları sözcük sayısındaki artışa katkıda bulunduğu saptanmıştır.

Tablo 3. Çocukların Bir Tümcede Kullandıkları Toplam Sözcük Sayısı

\begin{tabular}{|c|c|c|c|c|c|}
\hline & & \multicolumn{2}{|c|}{ Deney Grubu } & \multicolumn{2}{|c|}{ Kontrol Grubu } \\
\hline & & Ön Test & Son Test & Ön Test & Son Test \\
\hline Oyun & 2 sözcük & 62 & 11 & 57 & 61 \\
\hline \multirow[t]{9}{*}{ Etkinliğinde } & 3 sözcük & 93 & 38 & 92 & 90 \\
\hline & 4 sözcük & 62 & 47 & 61 & 61 \\
\hline & 5 sözcük & 23 & 57 & 24 & 22 \\
\hline & 6 sözcük & 3 & 40 & 8 & 8 \\
\hline & 7 sözcük & 1 & 19 & 2 & 3 \\
\hline & 8 sözcük & & 13 & 1 & 1 \\
\hline & 9 sözcük & 1 & 8 & - & - \\
\hline & 10 sözcük & - & 6 & - & - \\
\hline & 11-13 sözcük & - & 6 & - & - \\
\hline \multirow{12}{*}{$\begin{array}{l}\text { Türkçe } \\
\text { etkinliğinde }\end{array}$} & 2 sözcük & 28 & 4 & 40 & 24 \\
\hline & 3 sözcük & 68 & 12 & 51 & 80 \\
\hline & 4 sözcük & 81 & 30 & 59 & 50 \\
\hline & 5 sözcük & 47 & 45 & 46 & 35 \\
\hline & 6 sözcük & 8 & 39 & 25 & 24 \\
\hline & 7 sözcük & 6 & 27 & 4 & 14 \\
\hline & 8 sözcük & 3 & 19 & 5 & 9 \\
\hline & 9 sözcük & 4 & 15 & 3 & 4 \\
\hline & 10 sözcük & - & 10 & & 2 \\
\hline & 11-13 sözcük & - & 29 & 1 & 3 \\
\hline & 14-16 sözcük & - & 10 & 1 & - \\
\hline & 17 ve üstü & - & 4 & - & - \\
\hline
\end{tabular}

Dil gelişiminin bir başka ölçütü de bir tümce içindeki sözcüklerin sayısıdır. Yapılan analizlerde ön testlerde deney grubundaki çocuklar beş sözcükten uzun birkaç tümce kurarken, son testlerde çocukların kurdukları tümcelerin uzunluğu Türkçe etkinliklerinde 19 sözcüğe kadar çıkmıştır (Tablo 3). Örneğin; Beyaz bıyıkları, siyah her yeri, beyaz gözleri, ağzı, kaşları ve bıyıkları siyah olan bir kedi, çöpün, çöpte yiyecekler ariyor.

Öyle ki, deney grubunda özellikle Türkçe etkinliğinde son testlerde çocuklar çoğunlukla beş sözcükten daha uzun tümceler kurmuşlardır. Kontrol grubunda ise ön ve son testlerde çocukların kurdukları tümcelerin uzunluğunda çok fazla farklılaşma gözlenmemiştir. Çocuklar hem ön hem de son testlerde bir tümcede çoğunlukla 6 ve daha az sayıda sözcüğe yer vermişlerdir. Oyun etkinliği incelendiğinde de benzer sonuçlar gözlenmiş olup deney gurubundaki çocukların son testlerde kontrol grubundaki çocuklara oranla daha uzun tümceler kurdukları saptanmıştır. 
Uygulanan yaratıcı drama etkinlikleri içerisinde rol alan çocukların sürekli olarak, kendilerinin ve nesnelerin nerede, nasıl, ne şekilde, ne zaman, nasıl bir şey olduklarını nasıl hareket ettiklerini betimleyen ifadeler kullanması desteklenmiş ve çocukların daha uzun ve ayrıntıları anlatan ifadeler kullanması sağlanmıştır. Örneğin, lider, çocuklardan kendilerini donuk imge olarak oyuncakçı dükkanının vitrininde bir oyuncak olarak hayal etmelerini isterken çocuklara sürekli simgelediği oyuncağın özelliklerini sormuştur. Lider çocuklara "Nasıl bir oyuncaksın?”, "Ne renksin?”, "Neden yapılmışsın?", "Şeklin nasıl?", "Nası1 hareket eder ve çalışırsın?”, "Vitrinin neresinde nasıl duruyorsun?", "İnsanlar sana dokunduklarında neler hissederler?" gibi sorular yöneltmiştir. Etkinlikler sırasında çocuklara yöneltilen benzer özellikte sorular çocukların kurgularını daha kolay betimlemelerinde ve ifadelerinde daha ayrıntılı tümcelere yer vermelerinde etkili olmuş olabilir.

Deney grubundaki toplam sözcük sayısındaki artışın daha çok hangi sözcük türlerinde gerçekleştiğini incelemek için sözcük türleri de ayrı ayrı sayılmıştır. Bu çalışmanın amacına yönelik olarak ad, eylem, ön ad, belirteç ve ayrıca birden fazla tümcenin birlikte ifade edilmesini sağlayan ulaç ve ortaçların kullanımında bir farklılık olup olmadı̆̆ına da bakılmıştır.

Tablo 4. Çocukların Kullandıkları Ad Sayısı ve Mann-Whitney U Testi Sonuçları

\begin{tabular}{|c|c|c|c|c|c|c|c|c|c|c|c|}
\hline \multirow[t]{2}{*}{ Etkinlikler } & \multirow[t]{2}{*}{ Gruplar } & \multicolumn{5}{|c|}{ Ön Test } & \multicolumn{5}{|c|}{ Son Test } \\
\hline & & $\mathrm{N}$ & $\bar{X}$ & Std. Sap. & $\mathrm{U}$ & $\mathrm{P}$ & $\mathrm{N}$ & $\bar{X}$ & Std. Sap. & $\mathrm{U}$ & $\mathrm{P}$ \\
\hline $\begin{array}{l}\text { Türkçe } \\
\text { etkinliği }\end{array}$ & Kontrol & 7 & 49.28 & 10.51 & & 20.50 .607 & 7 & 64.42 & 21.39 & & $2.50 .005^{* *}$ \\
\hline Oyun & Deney & 7 & 26.00 & 6.13 & & 16.00 .275 & 7 & 64.85 & 19.88 & & $4.00 .009^{* *}$ \\
\hline \multirow{2}{*}{$\begin{array}{l}\text { Toplam } \\
\text { Sayısı }\end{array}$} & Deney & 7 & 71.28 & 8.11 & & \multirow[t]{2}{*}{15.50 .249} & 7 & 179.28 & 26.56 & & \multirow[t]{2}{*}{$.00 .002^{* *}$} \\
\hline & Kontrol & 7 & 80.00 & 14.71 & & & 7 & 96.71 & 24.17 & & \\
\hline
\end{tabular}

Hem deney hem de kontrol grubundaki çocukların ön testte kullandıkları ortalama toplam ad sayısı birbirine yakındır (sırasıyla 71.28 ve 80.00 ) ve arada anlamlı bir farklılık yoktur. Ancak, son testte belirgin bir farklılık gözlenmektedir. Yapılan Mann-Whitney U Testi sonuçları da her iki etkinlik için deney grubu ve kontrol grubunun ad kullanımları arasında istatistiksel olarak deney grubu lehine anlamlı bir farklılık olduğunu göstermektedir.

Tüm kültürlerde çocukların ilk öğrendikleri sözcüklerin isim olduğu, yaş ilerledikçe çocukların diğer sözcük gruplarını kullanmaya başladıkları belirtilmiştir (Gentner, 1982). Benzer şekilde, Türkçe’yi 
edinen çocukların da ilk aylarda baskın olarak ad türü sözcükler kullandıklarını ancak iki yaşlarından itibaren Türkçe'nin yapısal özelliği nedeni ile eylemlere odaklandıkları görülmüştür (TürkayAltınkamış, 2005).

Yaratıcı drama etkinlikleri çocuklara yeni yaşantılar, deneyimler sunarak, onların yeni kavramlar öğrenmesini ve öğrendiklerini yaşantı içerisinde kullanarak kalıcı hale getirmesini sağlar. Buna bağlı olarak çocukların tümcelerinde daha fazla ad kullanması da doğaldır. Yukarıdaki örneklere baktığımız zaman çocukların adları en çok betimleme yaptığı tümceler içerisinde kullandıkları görülmektedir.

Tablo 5. Çocukların Kullandıkları Eylem Sayısı ve Mann-Whitney U Testi Sonuçları

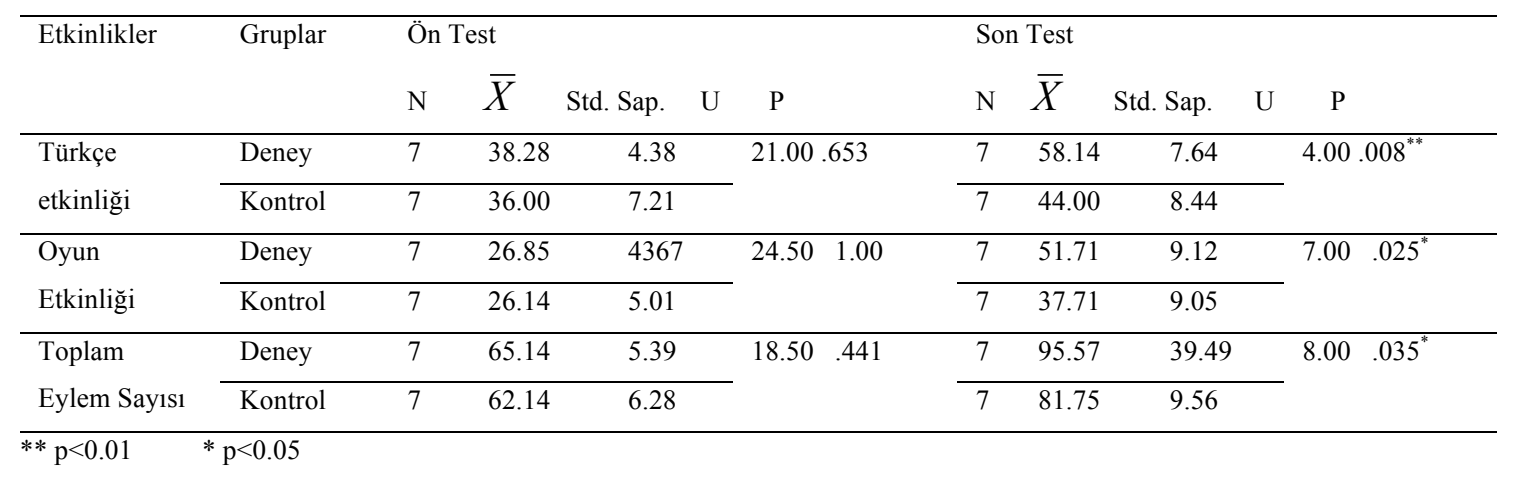

Kullandıkları eylem sayısı açısından deney ve kontrol gruplarının ön test ve son test puanları arasında istatistiksel olarak anlamlı farklılık bulunmuştur. Deney grubundaki çocuklar hem hikaye hem de oyun etkinliklerinde kontrol grubundaki çocuklara oranla anlamlı derecede daha fazla eylem kullanmışlardır.

Çocukların kullandıkları ortalama eylem sayısı arasındaki fark doğal olarak adlara oranla daha düşüktür. Her basit tümcede tek bir eylem varken aynı tümcede birden fazla ad olabilir. Bu nedenle, aynı sayıda tümce içinde daha az eylem ve daha fazla ad bulunabilir.

Çocuklar genelde karmaşık değil basit tümceler kullandıkları için her tümcede tek eylem bulunur (Braine, 1963). Bu çalışmanın verisi incelendiğinde çoğu tümcelerin basit olduğu ancak emir ifadeleri ya da birinin söylediği tümceyi başkalarına aktarma durumunda birden fazla eylem kullanıldığ görülmüştür.

Tablo 6. Çocukların Kullandıkları Sifat Sayısı ve Mann-Whitney U Testi Sonuçları 


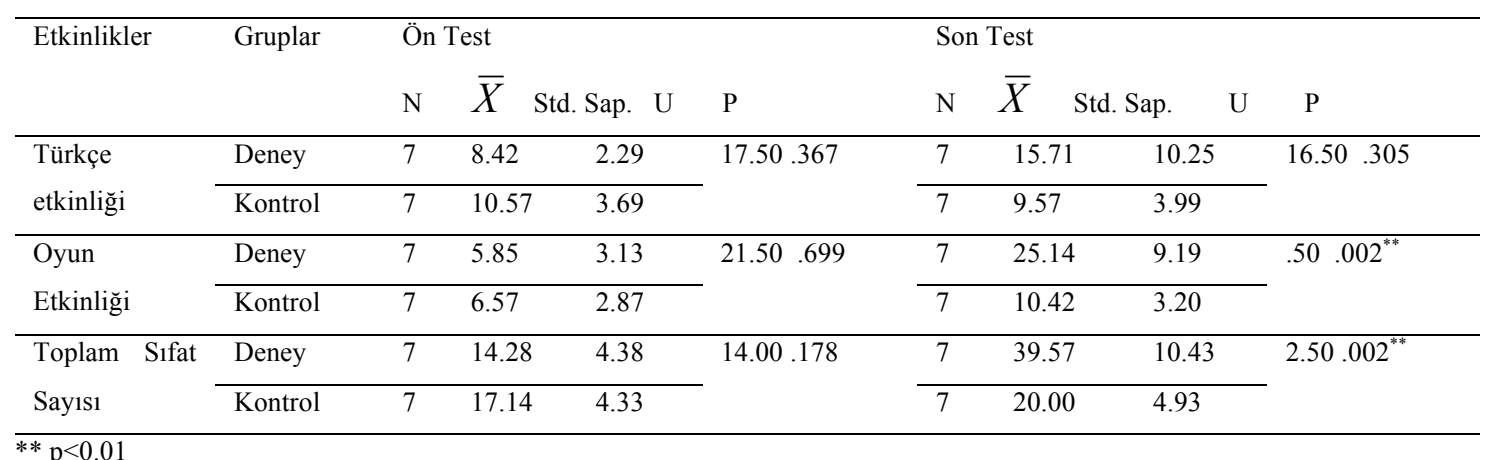

$* * \mathrm{p}<0.01$

Sıfatlar adları niteleyen sözcüklerdir. Sıfatlar, ya bir addan hemen önce ya da eylemlere benzer çekim ekleri almış durumda tümcenin sonunda yer alırlar. Her iki etkinlik için toplam sıfat sayısı incelendiğinde deney grubundaki çocukların ön testleri ( $\bar{X}=14.28)$ ve son testleri $(\bar{X}=39.57)$ arasında belirgin bir artış olduğu ve son testlerde deney grubundaki çocukların kontrol grubundaki çocuklara oranla daha fazla sıfat kullandıkları görülmektedir.

Yapılan analizler sonucunda da deney ve kontrol gruplarının son test puanları arasındaki bu farkın istatistiksel olarak anlamlı olduğu saptanmıştır $(\mathrm{p}<0.01)$. Türkçe etkinliklerinde her iki grupta benzer sayıda sıfat kullanılırken oyun etkinliğindeki artış toplamı etkileyecek kadar fazladır. Yaratıcı drama uygulamaları sırasında yapılan etkinlikler oyunla daha çok benzerlik göstermektedir. Deney grubundan çocukların kullandıkları sıfatlar arasında tek sözcüklü sıfatların yanısıra sıfat grupları, türemiş sıfatlar da görülmektedir: Örneğin: Temiz ekmek, mor çanta, kuyruklu kedi, kıvırcık saçlı çocuk.

Tablo 7. Çocukların Kullandıkları Belirteç Sayısı ve Mann-Whitney U Testi Sonuçları

\begin{tabular}{|c|c|c|c|c|c|c|c|c|c|c|}
\hline \multirow[t]{2}{*}{ Etkinlikler } & \multirow[t]{2}{*}{ Gruplar } & \multicolumn{4}{|c|}{ Ön Test } & \multicolumn{5}{|c|}{ Son Test } \\
\hline & & $\mathrm{N}$ & $\bar{X}$ & Std. Sap. U & $\mathrm{P}$ & $\mathrm{N}$ & $\bar{X}$ & Std. Sap. & $\mathrm{U}$ & $\mathrm{P}$ \\
\hline Türkçe & Deney & 7 & 11.28 & 6.84 & 24.00 .949 & 7 & 16.14 & 8.47 & & $11.00 \quad .084$ \\
\hline etkinliği & Kontrol & 7 & 10.28 & 3.90 & & 7 & 10.00 & 7.59 & & \\
\hline Oyun & Deney & 7 & 12.00 & 7.21 & 19.00 .481 & 7 & 15.28 & 7.18 & & $18.00 \quad .405$ \\
\hline Etkinliği & Kontrol & 7 & 8.71 & 4.27 & & 7 & 12.42 & 5.22 & & \\
\hline Toplam & Deney & 7 & 23.28 & 12.91 & 24.00 .949 & 7 & 31.42 & 8.24 & & $10.50 \quad .073$ \\
\hline Belirteç Sayısı & Kontrol & 7 & 19.00 & 4.43 & & 7 & 22.42 & 9.50 & & \\
\hline
\end{tabular}

Belirteçler, ya bir eylemi ya da bir sıfatı niteleyen sözcüklerdir, bu özellikleriyle eylemin nasıl yapıldığı konusunda fazladan bilgi verirler. Bu nedenle, kullanım zenginliği sağlarlar. Bu çalışmada, aşağıdaki Tabloda da görüldüğü gibi, istatistiksel olarak anlamlı bir farklılık olmamakla birlikte son 
testte deney grubunun kullandığı ortalama belirteç sayısı $(\bar{X}=31.42)$ kontrol grubunun ortalama belirteç sayısından ( $\bar{X}=22.42$ ) daha fazladir (Tablo 7).

İki grup arasında belirteç kullanımında istatistiksel fark olmaması belirteçlerin dilde diğer sözcüklere (ad ve eylemlere) oranla sayıca az olması olabilir. Buna karşın, çocuklar farklı belirteçleri kolayca kullanmaktadırlar. Örneğin: Bardağın içindeki suyu çabucak içmiş. Balık da onlara gizli gizli bakıyor.

Dil kullanımında zenginliğin bir diğer ölçüsü birden fazla sözcük ya da tümcenin birlikte kullanılmasını sağlayan bağlaçlar, ulaçlar ve ortaçlardır. Bu sözcük ve yapılar göreceli olarak geç edinilen birimlerdir (Sofu, 1995). Çünkü birden fazla tümceyi bağlamak için tümce yapılarının kullanılabiliyor olması gerekir. Bu nedenle, sözcük dağarcığının büyük bir kısmını oluşturan yukarıdaki sözcük türlerine göre, bağlaçlara, ulaç ve ortaçlara bu çalışmanın veri tabanında daha az rastlanmaktadır.

Bağlaçlar sayılarının az olmasının yanı sıra, kapalı sınıf sözcüklerdir. Yani, bir dildeki bağlaçların sayısı belirlidir ve açık sınıf diye adlandırılan ad, eylem, sıfat, vb'den farklı olarak sayıları zaman içinde fazla değişmez (Hengirmen, 1998; Fromkin ve Rodman, 1993). Buna karşın, çocukların bağlaç kullanımlarını incelediğimizde son testlerde deney grubundaki çocukların $(\bar{X}=21.14)$ kontrol grubundaki çocuklardan ( $\bar{X}=9.42$ ) istatistiksel olarak anlamlı derecede daha fazla bağlaç kullandığını görmekteyiz.

Tablo 8. Çocukların Kullandıkları Bağlaç Sayısı ve Mann-Whitney U Testi Sonuçları

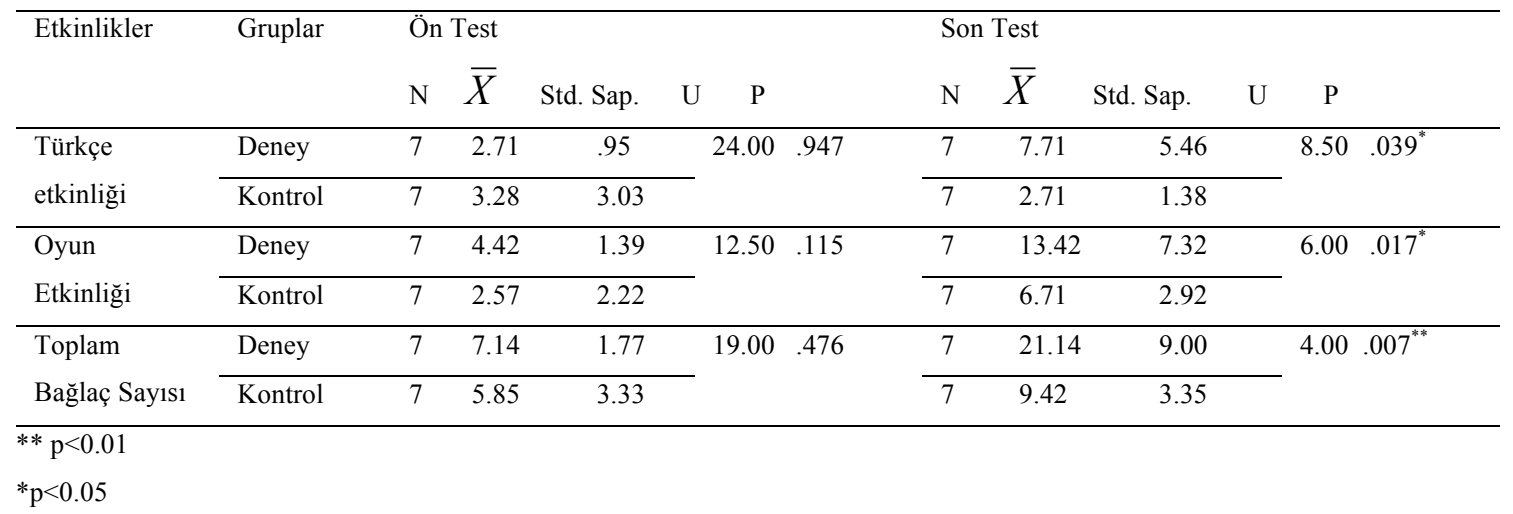

Çocukların kullandığı bağlaçlardan bir tanesi Türkçe'de günlük konuşmada çok fazla kullanılmayan, aşağıdaki örnekte görülen “ve” sözcüğüdür; Örneğin: Annesi, babası ve kardeşine yalan söyledi. 
Ulaçlar, iki tümcenin bağlanmasını sağlayan (koşarak geldi, dönüp durdu gibi) eylemlere eklenen eklerin oluşturduğu yapılardır. Ulaç kullanımı öncesi dönemde çocuklar bu iki tümceyi ayrı iki tümce halinde söylerler.

Tablo 9. Çocukların Kullandıkları Ulaç Sayısı ve Mann-Whitney U Testi Sonuçları

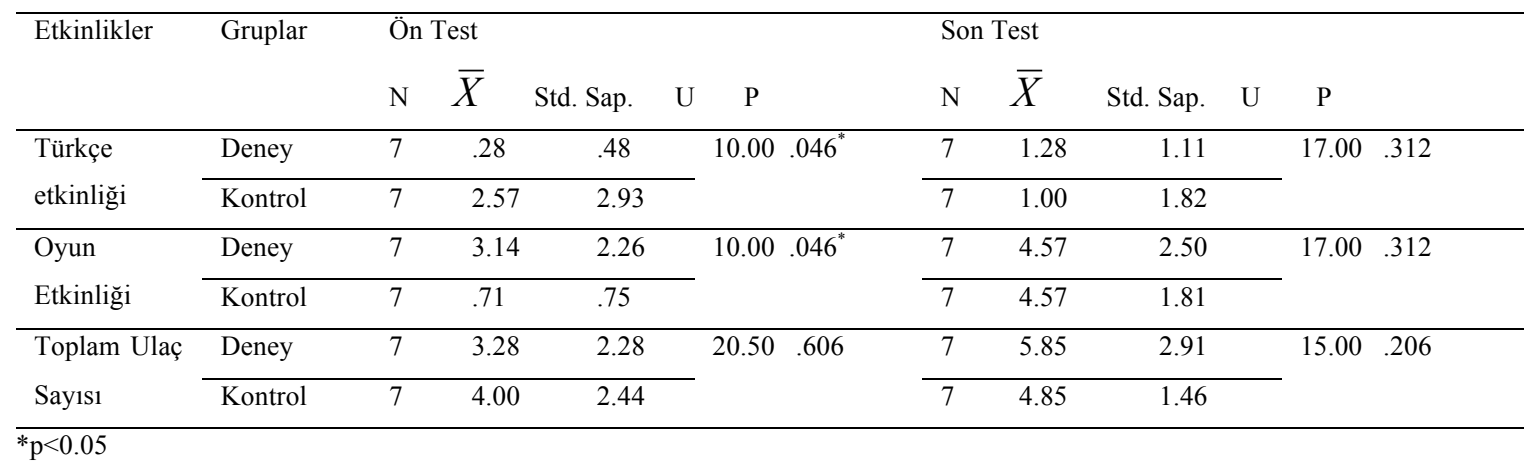

$\mathrm{Bu}$ çalışmada çocukların ulaç yapılarını az sayıda kullandıklarını görmekteyiz. Örneğin, deney grubunun ön testte kullandığı ortalama ulaç sayısı 3.28 iken, kontrol grubunun kullandı̆̆ı ulaç sayısı 4'tür. Ancak, istatistiksel olarak anlamlı olmamakla birlikte son testlerde deney grubunun ulaç kullanımında kontrol grubundan daha fazla artış gösterdiği anlaşılmaktadır (Tablo 9). Örneğin; Çıkarken, top yuvarlanmış yokuştan ve dikenleri çıkararak kavanoza koyup sonra onları bir çöp poşetine koyacağım demiş gibi.

Tablo 10. Çocukların Kullandıkları Ortaç Sayısı ve Mann-Whitney U Testi Sonuçları

\begin{tabular}{|c|c|c|c|c|c|c|c|c|c|}
\hline \multirow[t]{2}{*}{ Etkinlikler } & \multirow[t]{2}{*}{ Gruplar } & \multicolumn{4}{|c|}{ Ön Test } & \multicolumn{4}{|c|}{ Son Test } \\
\hline & & $\mathrm{N}$ & $\bar{X}$ & Std. Sap. U & $\mathrm{P}$ & $\mathrm{N}$ & Std. Sap. & $\mathrm{U}$ & $\mathrm{P}$ \\
\hline Türkçe & Deney & 7 & & .28 & $24.50 \quad 1.00$ & 7 & 1.42 & 2.29 & $19.00 \quad .410$ \\
\hline etkinliği & Kontrol & 7 & & .28 & & 7 & .28 & .48 & \\
\hline Oyun & Deney & 7 & & .57 & 14.00 .107 & 7 & 1.00 & 1.41 & $13.50 \quad .096$ \\
\hline Etkinliği & Kontrol & 7 & & .14 & & 7 & .14 & .37 & \\
\hline Toplam Ortaç & Deney & 7 & & .85 & $18.00 \quad .362$ & 7 & 2.42 & 2.50 & $13.00 \quad .117$ \\
\hline Sayıs1 & Kontrol & 7 & & .42 & & 7 & .42 & .53 & \\
\hline
\end{tabular}

Anlatıma zenginlik katan ve dil kullanımını basitten karmaşığa doğru taşıyan bir başka yapı ortaçtır. Ortaç, "uyuyan çocuk” örneğinde olduğu gibi, tümce içindeki ad türü bir sözcüğü betimlemek için 
kullanılan diğer bir tümcenin bağlanması için kullanılan bir yapıdır (Hengirmen, 1998). Ortaç ekini alan eylem nitelediği adın önüne yerleştirilir.

Yapılan analizlerde her iki gruptaki çocukların konuşma örneklerinde çok az sayıda ortaç kullandıkları görülmüştür. Ön testte çocuklar ortalama olarak birden daha az ortaç kullandıkları ve hem deney grubundan hem de kontrol grubundan bazı çocukların bu yapıyı hiç kullanmadığı saptanmıştır. Ancak, yaratıcı drama uygulaması sonrasında deney grubunun kullandığı ortaç sayısının daha fazla artış gösterdiği görülmüştür (Tablo 10). Örneğin: Gözünü kapatmış, gülümseyen bir çocuk. Çocuk, sandalyenin üzerine çıkıp masanın üzerinde duran kurabiyelerden alıyor gibi.

\section{Sonuç}

$\mathrm{Bu}$ çalışmada anaokuluna devam eden altı yaş grubu çocukların dil kullanımına yaratıcı drama etkinliklerinin katkısının olup olmadığı araştırılmıştır. Uygulama sonucunda yapılan son testlerde çocukların toplam sözcük sayısı, kullandıkları ortalama sözcük sayısı ve bir tümcede kullandıkları toplam sözcük sayısının deney grubundaki çocuklar lehine anlamlı farklılık gösterdiği saptanmıştır. Uygulama öncesi deney grubundaki çocuklar beş sözcükten uzun birkaç tümce kurarken, son testlerde özelikle Türkçe etkinliğinde çocukların kurdukları tümcelerin uzunluğu 19 sözcüğe kadar çıkmıştır.

Dilde temel sözcükler olan ad ve eylemlerin sayısında da deney grubu lehine belirgin bir artış gözlenirken, nesne ve eylemleri betimlemeye yarayan sıfat ve belirteçlerde belirgin bir artış gözlenmemiştir. Bununla birlikte sıfat ve belirteçlerdeki artış istatistiksel olarak anlamlı olmamakla birlikte, kullanılan sözcük sayılarının deney grubunda daha fazla olduğu görülmüştür. Birden fazla tümceyi bağlamak için kullanılan bağlaç, ulaç ve ortaçlar incelendiğinde, deney grubu lehine sayısal artış görülmüş̧ür. Özellikle, bağlaçlardaki bu artış istatistiksel olarak da anlamlıdır.

Sonuç olarak, her ne kadar çocuklarda dil gelişimi doğal bir süreç olup girdi olduğu sürece devam etse de yaratıcı drama etkinliklerinin bu süreci hızlandırdığı ve zenginleştirdiği söylenebilir. Bu sonuçlardan yola çıkarak, yaratıcı drama etkinliklerinin çocukların gelişimindeki diğer katkılarının yanı sıra dil kullanımlarına da katkıda bulunduğu ileri sürülebilir. Bu nedenle;

1. Okul öncesi eğitimde öğretmenlerin yaratıcı drama etkinliklerini yaygın olarak kullanmaları önerilebilir.

2. Alanda çalışan öğretmenlere yaratıcı drama etkinliklerini nasıl uygulayacakları ve bir yaratıcı drama etkinliğini nasıl planlayacakları ile ilgili hizmet içi eğitim kursları düzenlenebilir.

3.Dil ediniminin hızlı olduğu okul öncesi dönemde öğretmenler dilin çocuğun kendisini ifade etmesinde önemli bir araç olduğunu dikkate alarak günlük programlarında dil edinimine ilişkin çalışmalara daha fazla yer verebilir. 


\section{Kaynaklar}

Adıgüzel, H.Ö. (2002). Yaratıcı Drama. Ankara: Natürel Kitap Yayıncılık.

Alber, S. ve Foil, C. (2003). Yaratic1 drama activities that promote and extend your students vocabulary proficiency. Intervention in School \& Clinic, 39, (1), 22-29.

Braine, M. D. S. (1963). The ontogeny of English phrase structure: The first phase.

Language, 39, 1-13.

Fromkin, V. ve Rodman, R. (1993). An Introduction to Language. 5th edition. London: Harcourt Brace College.

Gentner, D. (1982). Why nouns are learned before verbs: linguistic relativity versus natural partitioning. A. Kuczaj (Haz.) Language Development. Vol 2: Language Thought and Culture (s. 301-334). Hillsdale, NJ: Erlbaum.

Hengirmen, M. (1998). Türkçe Dilbilgisi. Ankara: Nurol.

Koç, A. ve Slobin, D. I. (1985). Acquisition of Turkish. D. I. Slobin (Haz.) The Crosslinguistic study of language acquisition. (s. 839-878). London: Lawrence Erlbaum Associates.

Küntay, A. ve Slobin, D.I. (1996). Listening to a Turkish mother: some puzzles for acquisition. D.I. Slobin, J, Gerhardt, A. Kyratzis, \& J.Guo (Haz.) Social interaction, social context and language (s. 265-286). Mahwah, NJ: Lawrence Erlbaum Associates.

Mages, W.K. (2008). Does creative drama promote language development in early childhood? A review of the methods and measures employed in the empirical literature. Review of Educational Research, 78(1), 124-152.

McCaslin, N. (1990). Creative Drama in the Classroom. (5th ed.) CA: Players Press, Inc.

Savaşır I., Sezgin N. ve Erol N. (2005). Ankara Gelişim Tarama Envanteri El Kitabı, Kayıt Formu ve Değerlendirme Profilleri. Genişletilmiş Üçüncü Basım Ankara: Rekmay Ltd. Şti.

Sofu, H. (1995). Acquisition of Lexicon in Turkish. Yayınlanmamış Doktora Tezi, Çukurova Üniversitesi Sosyal Bilimler Enstitüsü, Adana.

Toye, N. ve Prendiville, F. (2000). Creative Drama and Traditional Story for the Early Years. London: Routledge Falmer.

Türkay-Altınkamış, N. F. (2005). Children's early lexicon in terms of noun/verb dominance, (Yayınlanmamış Doktora Tezi) Adana: Çukurova Üniversitesi Sosyal Bilimler Enstitüsü.

Uyar, N. (1995). Anaokuluna devam eden 60-72 aylık çocuklara destekleyici olarak uygulanan eğitimde drama programının çocukların dil gelişimine etkisi.(Yayınlanmamış Yüksek Lisans Tezi) Ankara: Hacettepe Üniversitesi Sağl1k Bilimler Enstitüsü.

\section{EK 1: Etkinlik örneği}


Konu: Duygularım

Yaş Grubu: Beş-altı yaş

Kullanılan materyaller: Farklı duygu ifadelerinin bulunduğu resimler, ipler ve kurdeleler Sosyal - Duygusal Alan

Amaç 2.Duygularını fark edebilme

Kazanımlar

1. Duygularını söyler.

2. Duygularının nedenlerini açıklar.

4. Duygularını müzik, dans, yaratıcı drama vb. yollarla ifade eder.

Bilişsel Alan

Amaç 16. Belli durum ve olaylarla ilgili neden-sonuç ilişkisi kurabilme

$\underline{\text { Kazanimlar }}$

1. Bir olayın olası nedenlerini söyler.

2. Bir olayın olası sonuçlarını söyler.

Amaç 18. Problem çözebilme

$\underline{\text { Kazanımlar }}$

1. Problemi söyler.

2. Probleme çeşitli çözüm yolları önerir.

3. Çözüm yolları içinden en uygun olanlarını seçer.

Dil Alanı

Amaç 3. Türkçeyi doğru kullanabilme

\section{Kazanımlar}

1. Konuşmalarında söz dizimi kurallarını doğru olarak kullanır.

2. Konuşmalarında temel dil bilgisi kurallarına uygun konuşur.

\section{Isınma ve Hazırlık:}

Lider çocukların arkalarına farklı duyguları anlatan resimler (mutlu, korkak, kızgın, şaşkın, üzgün) yapıştırır ve çocukların tüm alanı kullanarak müzik eşliğinde dans etmelerini ister. Müzik durduğunda çocukların verdiği yönerge ile birbirlerine dokunmalarını ister.

-Mutlu bir insana dokun, üzgün birine dokun... gibi

\section{Canlandırma:}

Sonra çocuklardan onlara vereceği ip ve kurdelelerle bir merdiven yapmalarını ister ve her basamağa çocukların sırtlarına yapıştırdığı bir resim bırakır ve çocuklara bunun bir duygu merdiveni olduğunu adım attıkları her basamaktaki duyguyu mimikleri ile göstermelerini ve nedenini anlatmalarını ister. Örneğin: Çıktığı basamakta gülen bir yüz gördüğünde önce güler sonra "Mutluyum çünkü annem bana pasta yapmış" diyerek duygusunun nedenini anlatır. Tüm çocuklar sırayla merdiveni tırmandıktan sonra lider çocuklara bir torba içerisine koyduğu eşit sayıdaki beyaz ve mavi kağıtlardan birer tane çekmelerini ister çocukların maviler ve beyazlar olarak karşı karşıya dizilmelerini ister. Karşı karşıya gelen çocuklar eş olurlar. Maviler anne rolünü beyazlar çocuk rolünü 
alırlar. Çocuklara sıra ile ortaya gelecekleri ve liderin söyleyeceği konuda konuşacakları anlatılır. Her grup sırası ile ortaya gelir. Lider elindeki kağıttan anne ve çocuklara durumu açıklar ve "Ben başla dediğimde konuşmaya başlayacaksınız" der. Konunun ve rollerin anlaşılıp anlaşılmadığını kontrol eder ve liderin başla komutu ile canlandırma başlar.

\section{Doğaçlamalar;}

-Annen sana pasta yapmış ama sen yaptı̆̆ pastayı sevmiyorsun. Başka bir pasta istiyorsun ama annenin başka pasta yapacak zamanı yok çünkü işe gitmek zorunda.

-Annenle markete gidiyorsun markette çok sevdiğin iki şey görüyorsun ve ikisini de almak istiyorsun ama annen sadece birini alabileceğini söylüyor

-Annen işe gitmek zorunda geç kalmış, acelesi var. Ama önce seni okula bırakması gerekiyor ama sen o gün okula gitmek istemiyorsun.

-Annen kedilerden korkuyor ama sen eve bir kedi getirmişsin. Kediyi beslemeyi çok istiyorsun. Annen kediyi evde istemiyor ama sen annene israr ediyorsun.

\section{Değerlendirme:}

Tüm çocuklarla birlikte bir araya gelinir. Çocukların etkinlik içerisinde neler yaşadıkları, duyguları, hakkında konuşulur. 


\title{
Summary
}

\section{The Effect Of Creative Drama on The Language Utilization of 6 Year-Old Children}

\author{
Yaşare AKTAŞ ARNAS. Binnur CÖMERTPAY* $\quad$ Hatice SOFU*.. \\ Çukurova University
}

Language acquisition is a life-long process which starts at birth. However, the rate of acquisition is high at earlier ages in comparison with later ages. Children are born into an environment in which one or more languages are spoken, consequently, their language acquisition capacity is triggered by the input they are exposed to. Acquisition of the first language is more or less completed within the first 6 years. Social environment and communication style in the family and characteristics of the language in question influences the nature of this process. For example, Turkish is a language acquired relatively in early ages because inflectional suffixes are transparent. Therefore, children acquire most structures in the first two years and later they add some complicated structures and vocabulary items (Koç \& Slobin, 1985).

Immediate environment is very important in shaping the language a child uses. Children are first exposed to dialogues, games, stories, and songs around them. They imitate the sounds they hear, join social activities and communicate with adults and other children. Language acquisition takes place in natural environment. The most suitable natural environment for children is playing games and situations that are similar to playing. One way of providing such an environment is creative drama.

Creative drama is an invaluable tool for developing speaking skills, learning new vocabulary, and using language creatively. Moreover, it enhances active thinking and increases questioning skills of children (Toye \& Prendiville, 2000). Creative drama also contributes to language acquisition by providing new roles and perspective. Thus, it is an effective way of developing the language acquisition process with its game-like and natural features.

Creative drama not only enhances verbal expressions of children but also contributes to their lexical development. In creative drama process, children come across situations that they have not experienced

\footnotetext{
Prof. Dr., Çukurova University, Education Faculty, E-mail: yasare@cu.edu.tr

. Msc., Çukurova University, Education Faculty, E-mail: comertpay@gmail.com

... Assoc.Prof. Dr., Çukurova University, Education Faculty,E-mail: hasofu@cu.edu.tr
} 
before. Thus, they learn appropriate vocabulary items within the new situations. Creative drama also helps children to learn abstract words by animation (McCaslin, 1990).

According to Toye and Prendiville (2000), creative drama provides context for communication, imaginary roles and perspectives, and new relations. Thanks to creative drama, children are exposed to dialogues instead of monologues of teachers, listening is improved, and the way children positioned enhances and encourages communication.

In addition to acquisition of new words, we believe creative drama triggers the already stored words in children's minds; hence, they become more productive. For this reason, in this study, we aimed to find out the effect of creative drama on the development of language use of six-year-old children attending Çukurova University kindergarten. Fourteen children, seven in the control group and seven in the experimental group were chosen at the end of assessment with Ankara Developmental Assessment Inventory. The children in the control group were taught by their own instructor following the curriculum; whereas, the children in the experimental group were introduced creative drama after the pretest. Fifteen creative drama activities enhancing their language use were used twice a week for a duration of 8 weeks. The data collected through games and story telling activities were recorded and transcribed. The first 35 utterances children used were analyzed in terms of sentence length, word counts, and different word classes.

The results showed the children who received creative drama sessions used more words and longer and more complex sentence structures than those who did not. The difference between the two groups was also statistically significant. Children who used two-word sentences on avarage started using sentences as long as 17 words. There was also a significant increase in the number of nouns and verbs, the basic word groups in languages, in favor of the creative drama group. In comparison to nouns and verbs, we expected a substantial raise in the number of adjectives and adverbs used for describing objects, entities, people, and actions. Contrary to our expectations, although the number of adjectives and adverbs used by the creative drama group was higher than those used by the control group, this difference was not statistically significant. There was also an increase in the number of conjunctions, gerunds, and adverbials which are used to combine more than one clauses in favor of the creative drama group. Specifically in conjunctions this increase was statistically significant.

To sum up, we have seen that language used by children at six years of age becomes richer thanks to creative drama. In addition to its contributions to the general development of children, creative drama makes children use their linguistic potential. Thus, it is suggested that teachers in preschool education should make use of creative drama activities in their classes.

\section{Creative Drama Journal}

